\section{COMPARATIVE ANALYSIS OF ADVANTAGES OF COFFEE FARMING WITH DIFFERENT CULTIVATION SYSTEMS AND PLANTING DISTANCES}

\author{
Suryadi $^{1}$, Fadli $^{2}$, Irada Sinta ${ }^{3}$ \\ 1,2,3 Faculty of Agriculture, Universitas Malikussaleh \\ Corresponding Author : $\underline{\text { irada@ unimal.ac.id }}$
}

\begin{abstract}
Coffee plants in general are one of the plantation commodities that are suitable for smallholder plantations because they can produce fruit throughout the year. Coffee production can be used as a source of daily or weekly income for the community. The problem in the upstream subsystem is that the productivity of Indonesian coffee plants is still below its normal potential and tends to decrease. One of the reasons for this low productivity is the cultivation system, starting from maintenance, pruning and fertilizing, as well as plant spacing. The difference in treatment in the coffee cultivation system will also affect the profits that will be obtained by farmers. This study aims to analyze the differences in the profits of coffee farming with a spacing of $2.5 \times 2.5 \mathrm{~m}$ with a spacing of $1.5 \times 1.5$ $m$ and different cultivation systems. This research uses descriptive quantitative method using profit analysis and profit difference test. The results showed that the spacing of $1.5 \times 1.5 \mathrm{~m}$ is more profitable than the spacing of $2.5 \times 2.5 \mathrm{~m}$. This happened because the population per hectare at a spacing of $1.5 \times 1.5 \mathrm{~m}$ was 4,444 plants accompanied by very intensive care, while at a spacing of $2.5 \times 2.5 \mathrm{~m}$ the population was only 1,600 plants. The follow-up to the results of this research will be submitted to the Sinta-2 journal by preparing articles according to the format given to the journal in question. This happened because the population per hectare at a spacing of $1.5 \times 1.5 \mathrm{~m}$ was 4,444 plants accompanied by very intensive care, while at a spacing of $2.5 \times 2.5 \mathrm{~m}$ the population was only 1,600 plants. The follow-up to the results of this research will be submitted to the Sinta-2 journal by preparing articles in accordance with the format given to the journal in question. This happened because the population per hectare at a spacing of $1.5 \times 1.5 \mathrm{~m}$ was 4,444 plants accompanied by very intensive care, while at a spacing of $2.5 \times 2.5 \mathrm{~m}$ the population was only 1,600 plants. The follow-up to the results of this research will be submitted to the Sinta-2 journal by preparing articles in accordance with the format given to the journal in question.
\end{abstract}

\section{Keywords : Comparative Analysis, Arabica coffee, profit}

\section{INTRODUCTION}

The agricultural sector in a broad sense includes the food crops sub-sector, plantation subsector, forestry sub-sector, fisheries sub-sector, and fishery sub-sector. The plantation sub-sector is a supporting sub-sector in the agricultural sector in the Indonesian economy. Coffee is one of the export commodities from the plantation sub-sector which is the national leading commodity after oil palm, rubber, and coconut. Coffee plants in general are one of the plantation commodities that are suitable for smallholder plantations because they can produce fruit throughout the year. Coffee production can be used as a source of daily or weekly income for the community.

The development of coffee commodities in Indonesia cannot be separated from various problems faced from the upstream to downstream subsystems. The problem in the upstream subsystem is that the productivity of Indonesian coffee plants is still below its normal potential and tends to decrease. The problem in the downstream subsystem that affects the Indonesian coffee trade is the low quality of coffee due to post-harvest handling that is not in accordance with GHP (Good Handling Practices). Central Aceh Regency is a central area for coffee cultivation in Aceh Province, 
especially Arabica coffee which has the potential to reach 1.5 tons/ha/year. But in reality the new productivity can be achieved at $745 \mathrm{~kg} / \mathrm{ha} / \mathrm{year}$. One of the reasons for this low productivity is the cultivation system, starting from maintenance, pruning and fertilizing, as well as plant spacing.

However, there are some farmers who have started to carry out a new innovation. This more intensive cultivation (4444 plants per ha) requires higher costs due to the higher number of seeds needed and higher maintenance costs. The difference in treatment in the coffee cultivation system will also affect the profits that will be obtained by farmers. In the cultivation system which is generally carried out by local farmers, the income obtained is still small due to low production and low costs. Meanwhile, in a more intensive cultivation system, the costs incurred will increase and the income earned will also increase.

\section{IMPLEMENTATION METHOD}

\subsection{Location, Object, and Scope of Research}

This research conducted in Central Aceh District. The location selection was done purposively because Central Aceh Regency is a center for coffee production. The object of research is coffee farmers who carry out cultivation systems with a spacing of $2.5 \times 2.5 \mathrm{~m}$ and a spacing of $1.5 \times 1.5 \mathrm{~m}$. The scope of this research is limited to see if there are differences in the benefits of different plant spacings accompanied by different cultivation systems.

\subsection{Data Types and Sources}

In this study using two sources of data, namely primary data and secondary data. Primary data is data obtained directly from the field on farmers who do coffee farming. Secondary data is data obtained through literature study by collecting relevant theories and literature such as books, research journals, theses and data from other agencies such as BPS (Central Bureau of Statistics) and the Department of Agriculture.

\subsection{Population and Sample}

The population in this study are coffee farmers who cultivate with different spacing and cultivation systems. The sampling method for farmers who practice cultivation systems with a spacing of $1.5 \times 1.5 \mathrm{~m}$ is 15 farmers and for farmers with a spacing of $2.5 \times 2.5 \mathrm{~m}$ as many as 20 farmers.

\subsection{Data analysis method}

The method used in this study is a quantitative descriptive method using profit analysis and test different advantages.

\subsubsection{Calculating Profit}

The advantages of coffee farming with a spacing of $2,5 \times 2.5 \mathrm{~m}$ and $1.5 \times 1.5 \mathrm{~m}$ are influenced by the size of the costs incurred and the production value obtained. These production costs include equipment depreciation costs, labor costs, fertilizers, pesticides, fungicides and other costs.

\subsubsection{Test of Variance}

To determine which t-test formula is To be used first, the magnitude of the population variance $\left(S^{\wedge} 2\right)$ must be known.

\subsubsection{Differential Test}

To analyze whether there is a significant difference between the profits of coffee farming with a spacing of $2.5 \times 2.5 \mathrm{~m}$ and a spacing of $1.5 \times 1.5 \mathrm{~m}$ used different tests. If the sample of the first group is not equal to the number of samples of the second group ( $\left.n \_1 n \_2\right)$ and the variance is homogeneous, then the polled variance formula is used

In this study, data analysis used the SPSS program tool for independent t-test testing.

\section{RESULTS AND DISCUSSION}

\subsection{Analysis of Coffee Farming}




\section{ORFAI JOURNAL Multidiciplinary Output Research For Actual and International Issue}

\subsubsection{Characteristics of Coffee Farmers}

1. Age

Table 1. Characteristics of Farmers by Age

\begin{tabular}{lccc}
\hline No & Umur (tahun) & Jumlah & Persentase (\%) \\
\hline$(1)$ & $(2)$ & $(3)$ & $(4)$ \\
\hline 1. & $15-50$ & 27 & 77,14 \\
2. & $\geq 50$ & 8 & 22,86 \\
3. & $>64$ & 0 & 0 \\
\hline \multicolumn{2}{c}{ Total } & 35 & 100 \\
\hline
\end{tabular}

Source: Primary Data (Processed), 2021

Based on Table 1, it can be seen that the average age of farmers in coffee farming in Central Aceh Regency is still in the productive age (15-64 years). Farmers belonging to this productive age have energy, body strength and high morale. At productive age, it is possible for a farmer to be able to increaseskills in farming by absorbing and adopting new technology in farming where better farming skills are expected to increase farmers' income and farm productivity.

\section{Education}

Table 2. Characteristics of Farmers Based on Education Level

\begin{tabular}{llcc}
\hline No & Tingkat Pendidikan & Jumlah & Persentase (\%) \\
\hline$(1)$ & $(2)$ & $(3)$ & $(4)$ \\
\hline 1. & SD & 2 & 5,7 \\
2. & SMP & 8 & 22,9 \\
3. & SMA & 19 & 54,3 \\
4. & S1 & 6 & 17,1 \\
\hline \multicolumn{2}{l}{ Total } & 35 & 100,0 \\
\hline
\end{tabular}

Source: Primary Data (Processed), 2021

Based on Table 2, it can be seen that the education level of the respondents is mostly at the high school (SMA) level, which is as many as 19 people. Higher educated farmers are easy to accept new innovations so it is easier to learn and practice better coffee cultivation systems.

\section{Land Area}

Coffee land area is the amount of land managed by coffee farmers which is measured in hectares. The average land area of farmers who cultivate coffee with a spacing of $2.5 \times 2.5 \mathrm{~m}$ is 0.7 ha, while farmers who cultivate coffee with a spacing of $1.5 \times 1.5 \mathrm{~m}$ are 1 ha.

\section{Experience}

The characteristics of coffee respondents in Central Aceh Regency based on the experience of managing coffee plants are 12 years for a garden spacing of $2.5 \times 2.5 \mathrm{~m}$ and 6 years for a spacing of $1.5 \times 1.5 \mathrm{~m}$ respectively.

Farming experience affects the ability of farmers to manage and make decisions in their farming. The longer the farmer cultivates, it can affect the habits, skills and skills or expertise in carrying out farming activities which will affect whether or not production results are good. Coffee farmers have varied experiences in running coffee farming, ranging from 3-15 years.

\subsection{Production cost}

\subsubsection{Equipment Depreciation Cost}

Availability of equipment and materials Sufficient and adequate raw materials will facilitate the production process so as to increase yields and profits for coffee farmers. Equipment depreciation costs are included in fixed costs, which are not used up once and the amount is not affected by the amount of output produced. The average amount of equipment depreciation expense incurred in coffee farming with a spacing of $2.5 \times 2.5 \mathrm{~m}$ is Rp. 2,050,000 per year and the average depreciation expense incurred by coffee farmers with a spacing of $1.5 \times 1.5 \mathrm{~m}$ is Rp. 2,135,000 per year. 


\subsubsection{Land Lease Fee}

Land is a medium or a place to grow plants and is the most important production factor in farming activities. The wider the area of land cultivated by farmers, the greater the production produced, on the contrary, the narrower the land cultivated by farmers, the smaller the production produced. The average cost of renting land in Central Aceh Regency is IDR 10,000,000 per hectare per year.

\subsubsection{Cost of Fertilizer and Pesticide}

Fertilizer is one of the production factors that can increase crop yields if its use is optimal, namely the dose of fertilizer is adjusted to the needs of the plant. Fertilization is a must, because each period of plant life depletes the availability of nutrients in the soil. The average cost incurred by coffee farmers with a spacing of $2.5 \times 2.5 \mathrm{~m}$ is Rp. $4.250 .000 / \mathrm{ha}$, while the average cost incurred by coffee farmers with a spacing of $1.5 \times 1.5 \mathrm{~m}$ is Rp.6.760.000/ha. Pesticides are substances used to control, reject oreradicatenuisance organisms. The use of pesticides is carried out in accordance with the recommended use or in accordance with the required dose. Pesticides used by coffee farmers are fungicides and insecticides. The cost incurred by coffee farmers with a spacing of $2.5 \times 2.5 \mathrm{~m}$ is Rp. 750,000 and a farmer with a spacing of $1.5 \times 1.5 \mathrm{~m}$ is Rp. $1.340,000$.

\subsubsection{Labor Cost}

Labor is an important part of the factors of production in an effort to maximize productive efforts both on the qualitative side and on the quantitative side. In general, the use of labor is highly dependent on the type of farming work and the number of plant populations per hectare. Labor costs include the costs of fertilizing, spraying, pruning, sanitizing, and harvesting. The average labor cost for coffee cultivation with a spacing of $2.5 \times 2.5 \mathrm{~m}$ is Rp. 140,900,000, while for coffee cultivation with a spacing of $1.5 \times 1.5 \mathrm{~m}$ it is Rp. $366,515,000$.

\subsubsection{Total Cost}

Table 3. Average Cost of Coffee Farming per hectare per Year

\begin{tabular}{|c|c|c|c|}
\hline \multirow{2}{*}{ No } & \multirow{2}{*}{ Uraian } & \multicolumn{2}{|c|}{ Biaya (Rp) } \\
\hline & & $2,5 \times 2,5 \mathrm{~m}$ & $1,5 \times 1,5 \mathrm{~m}$ \\
\hline (1) & (2) & (3) & (4) \\
\hline 1. & Peralatan & 2.050 .000 & 2.135 .000 \\
\hline 2. & Pupuk & 4.250 .000 & 6.760 .000 \\
\hline 3. & Pestisida & 750.000 & 1.340 .000 \\
\hline 4. & Fungisida & 1.500 .000 & 1.500 .000 \\
\hline \multirow[t]{6}{*}{3.} & Tenaga Kerja & & \\
\hline & Pemupukan & 2.500 .000 & 4.000 .000 \\
\hline & Penyemprotan & 1.400 .000 & 1.000 .000 \\
\hline & Pemangkasan & 16.000 .000 & 44.440 .000 \\
\hline & Sanitasi & 9.000 .000 & 6.000 .000 \\
\hline & Pemanenan & 112.000 .000 & 311.075 .000 \\
\hline \multirow[t]{2}{*}{4.} & Sewa Lahan & 10.000 .000 & 10.000 .000 \\
\hline & Total biaya $/ \mathrm{Ha}$ & 159.450 .000 & 388.250 .000 \\
\hline
\end{tabular}

Source: Primary Data (Processed), 2021

From table The above shows that the costs incurred by farmers with closer spacing of $1.5 \mathrm{x}$ $1.5 \mathrm{~m}$ are higher than coffee farming with longer spacings $(2.5 \times 2.5 \mathrm{~m})$. This is especially the case because the relatively large number of plant populations per hectare will cause costs for pruning and harvesting to be large as well.

\subsubsection{Coffee Farming Acceptance}

The average income from coffee farming with different spacing can be seen in the table below. Table 4. Average Coffee Farming Revenue per Hectare per Year 


\section{ORFAI JOURNAL Multidiciplinary Output Research For Actual and International Issue}

\begin{tabular}{lccr}
\hline No & Uraian & $\begin{array}{c}\mathbf{2 , 5} \times \mathbf{2 , 5 m} \\
\text { (Per Ha/tahun) }\end{array}$ & $\begin{array}{c}\mathbf{1 , 5} \times \mathbf{1 , 5 m} \\
\text { (Per Ha/tahun) }\end{array}$ \\
\hline$(1)$ & $(2)$ & $(3)$ & $(4)$ \\
\hline 1 & Produksi (kaleng) & 4.480 & 12.443 \\
2 & Harga (Rp/kaleng) & 60.000 & 60.000 \\
3 & Penerimaan (Rp) & 268.800 .000 & 746.580 .000 \\
\hline
\end{tabular}

Source: Primary Data (Processed), 2021

Table 4 explained that the average coffee production with a spacing of $2.5 \times 2.5 \mathrm{~m}$ is 4,480 cans of red logs per hectare per year, while the production of coffee with a spacing of $1.5 \times 1.5 \mathrm{~m}$ is 12,443 cans per hectare per year. The average selling price of red coffee logs per can is IDR 60,000 . The average acceptance of coffee with a spacing of $2.5 \times 2.5 \mathrm{~m}$ with $1.5 \times 1.5 \mathrm{~m}$ is Rp. $268,800,000$,/ha/year and $\mathrm{Rp} 746,580,000,-/$ ha/year. The difference in the number of receipts is due to more coffee production with closer spacing.

\subsection{Coffee Farming Benefits}

The comparison of the advantages for the two spacings can be seen in the following table.

Table 5. Average Profit of Coffee Farming per Hectare per Year

\begin{tabular}{llcc}
\hline No & Uraian & $\begin{array}{c}\mathbf{2 , 5} \times \mathbf{2 , 5 m} \\
\text { (Per Ha/Tahun) }\end{array}$ & $\begin{array}{c}\mathbf{1 , 5} \times \mathbf{1 , 5 m} \\
\text { (Per Ha/Tahun) }\end{array}$ \\
\hline$(1)$ & \multicolumn{1}{c}{$(2)$} & $(3)$ & $(4)$ \\
\hline 1. & Penerimaan (Rp) & 268.800 .000 & 746.580 .000 \\
2. & Biaya usahatani (Rp) & 159.450 .000 & 388.250 .000 \\
4. & Keutungan/Ha (Rp) & 109.350 .000 & 358.330 .000
\end{tabular}

Source: Primary Data (Processed), 2021

Based on Table 5 it can be seen that the average profitcoffee farms that do planting with a spacing of $2.5 \times 2.5 \mathrm{~m}$ amounting to Rp. 109.350.000/ha/year and the profit from planting with a spacing of $1.5 \times 1.5 \mathrm{~m}$ is Rp. 358.330.000/ha/year. The difference in profits is caused by differences in the number of plant populations which will ultimately lead to differences in production.

\subsection{Outcome}

Because a comparative analysis has not been carried out, the output in the form of being submitted to the journal has not been carried out until the reporting of research progress is at the $70 \%$ stage.

\section{CONCLUSION}

Based on the analysis carried out, it can be concluded that coffee farming with a spacing of $1.5 \mathrm{x}$ $1.5 \mathrm{~m}$ will provide greater benefits than the spacing of $2.5 \times 2.5 \mathrm{~m}$.

\section{REFERENCES}

Central Bureau of Statistics. 2020. Statistics of Indonesian Coffee. Central Jakarta.

Daniel, M. 2015. Introduction to Agricultural Economics. Jakarta: Earth Literacy.

Fahruddin, H., Yulianti K., Sulaeman. 2019. Comparative Analysis of Side-Splitting and Top-Cut

Cocoa Farming Income in the Village West Sidole, Ampibado District, Parigi Mautong

Regency. Journal. Faculty of Agriculture. Tadulako University.

Hassan. 2012. Analysis of Research Data with Statistics. Jakarta: Graphics. 
Misbahuddin, Iqbal. 2013. Research Data Analysis with Statistics. Jakarta: Earth Literacy.

Mustapa. 2013. Comparative Analysis of Oil Palm Farming Income for Iga and Plasma Groups in Gunung Sari Village, Pasangkayu District, North Mamuju Regency. Essay. Faculty of Agriculture. Tadulako University.

Nazir. 2005. Research Methods. Jakarta: Ghalia Indonesia.

Purnomo, A. 2011. The Concept of Income and Profit. Jakarta: Rineka Cipta.

Rahim and Hastuti. 2017. Agricultural Economics, Introduction to Theory and Cases. Self-Help Spreader.

Sinaga, R. 2019. Comparative Analysis of Profits from Semi-Organic and Non-Organic Arabica Coffee Farming in Raya District, Simalungun Regency. Journal. Faculty of Agriculture. Malikussaleh university.

Soekarno. 2011. Farming Analysis. Jakarta: University of Indonesia.

Sugiyono. 2014. Qualitative Quantitative Research Methods and R\&D. Bandung: Alphabeta.

Sukirno, S. 2012. Introduction to Microeconomic Theory. Jakarta: PT. Salemba.

Suratiyah, K. 2012. Farming Science. Jakarta: Self-Help Spreader.

\section{Notes:}

Thank's A Lot To Radja Publica As The Head Officer Of Ijebas Journal Who Has Facilitated The Process Of Publishing This Scientific Article And Also Especially To Lppm Malikussaleh University. Who Is Willing To Cooperate In The Process Of Publishing Articles About Comparative Analysis Of The Advantages Of Coffee Farming With Different Cultivation Systems And Spacing. 